\title{
The Image of the King and Its Architectural Spaces in Al-Andalus and Castile and in the Larger Context of the Mediterranean
}

\author{
Juan Carlos Ruiz Souza $(\dagger)$
}

\begin{abstract}
Al-Andalus and Castile in the Genesis of the 'Modern State.' Artistic Synergies in a Shared Cultural Context
\end{abstract}

The development of palatine architecture in Al-Andalus did not go unnoticed by the Christian kingdoms of the north. ${ }^{1}$ The Crown of Castile, involved

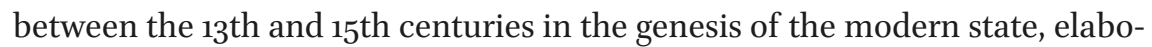
rated and created a new concept of a specialised palace that was not exempt of Andalusian contributions. A palace where there are spaces and rooms with specific functions. A true palatine city was created, as it is still being studied, in the Royal Alcazar of Seville, where the Castilian monarchy developed its spaces of representation, or rather of exaltation, of the king and his sovereignty. In those spaces, the king exposed and lead, without competition from ecclesiastics and nobles, the plans for his kingdom, as the only lord of so many good people, and such great lands', as recalled in the prologue of Las Partidas of Alfonso x. ${ }^{2}$

During that process, the buildings of al-Andalus were appropriated, copied, and emulated to diverse degrees in the Crown of Castile, as the artistic forms show. ${ }^{3}$ Decorative elements, spaces, or even ideological messages were adopted, as is shown in a number of royal and noble palaces erected between the 14th and $15^{\text {th }}$ centuries. The reign of Pedro I (1350-1369) was especially relevant in this sense, during which important palatine complexes were built, such as the Alcazar of Seville, the Alcazar of Carmona (Seville), the royal

1 This article is based on materials examined in the framework of the National R\&D Plan of the Ministry of Economy and Competitiveness of Spain: Al-Andalus, ciencia y contextos en un Mediterráneo abierto. De Occidente a Egipto y Siria. AL-ACMES: RTI 2018-o9388o-B-10o.

2 Alfonso x, Las Siete Partidas, Glosadas por el licenciado Gregorio López del Consejo Real de Indias de su Magestad, Salamanca 15551 (Edición facsimilar Madrid, 1985), fols. 3r, 3v.

3 Juan Carlos Ruiz Souza, "Castilla y Al-Andalus. Arquitecturas aljamiadas y otros grados de asimilación," Anuario del Departamento de Historia y Teoría del Arte (U.A.M.) 16 (2004), 17-43.

(C) JUAN CARLOS RUIZ SOUZA, 2022 | DOI:10.1163/9789004511583_016

This is an open access chapter distributed under the terms of the CC BY-NGat.odicense.Ruiz Souza - 9789004511583 
palace in which the convent of Santa Clara de Tordesillas (Valladolid) was founded in 1363 by Peter I's daughters, or the convent-palace of Santa Clara de Astudillo (Palencia). The monarch saw in the architecture of Al-Andalus, and in particular in the Alhambra of Muhammad v (Figure. 14.1), the specialized palace (including throne rooms, monumental façades with inscriptions, halls of justice, knowledge spaces, and courtyards) that he needed for his political project of strengthening royal power: the Genesis of the modern state. The palace was, indeed, a keystone in that process, being the space in which the king's new image was publicly exhibited. Thus, the despotic character of the Muslim rulers, who held both political and religious power, seemed to be a source of inspiration for the new concept of Christian King. The relationship between the palatine architectures of Al-Andalus and those undertaken by the Castilian-Leonese Crown is apparent in the shared visual culture of power, as is evidenced by its forms, meanings and messages and, in particular, by the resemblance among the different typologies of façades and throne rooms, as well as the use of decorative elements reminiscent of al-Andalus.

\section{Andalusian Architectural Typologies in Castilian Palaces. Bahw, Qubba, and Monumental Façades with Inscriptions}

The palatine examples preserved from the Almohad period in Seville and from the Nasrid period in the Alhambra clearly exerted their influence on the royal architecture of Castile. The bahw type, ${ }^{4}$ also known as the inverted ' $T$ ', can be found in the northern side of Comares Palace, where the rectangular-planned Sala de la Barca (Hall of the Boat) serves as the narthex of the square-planned Salón de Embajadores (Hall of Ambassadors). Earlier examples of this type have been discovered in the 13th-century palace of the convent of Santa Clara, in Seville. ${ }^{5}$

4 Alfred Dessus Lamare, "Étude sur le bahw, organe d'architecture musulmane," Journal Asiatique (1936), 529-47.

5 There is no consensus on the dating of the medieval remains and plasterworks of the convent of Santa Clara in Seville. Scholars agree that they could date from the 13th century, but with two possibilities: either before or after 1248, the year when the Christian troops of Ferdinand III captured the city. See: Pablo Oliva Muñoz, and Miguel Ángel Tabales Rodríguez, "Los restos islámicos y el Palacio de don Fadrique," in Real Monasterio de Santa Clara. 2 Palacioy Cenobio, ed.José Solís Guzmán(Sevilla, 2007), pp.13-21; Pablo Oliva Muñoz, Alfonso Jiménez Sancho, and Miguel Ángel Tabales Rodríguez, "Primera fase de estudios arqueológicos en el Real Monasterio de Santa Clara de Sevilla," Anuario Arqueológico de Andalucía 2003 1 (Sevilla, 2006), pp. 336-51; Miguel Ángel Tabales Rodríguez, "Novedades arqueológicas relativas a los palacios medievales de Don Fadrique y Alcázar Real," in $L a$ 
The same formula found at the Alhambra was repeated subsequently in the Alcazar of Guadalajara and in the palace in which the convent of Santa Clara was founded in Toledo. We note the same rectangular-planned halls, with or without alcoves at their ends and accessible through the centre of their long side, as well as the square-shaped halls known as qubba, crib or alcove. ${ }^{6}$ It is also worth recalling the Imperial Palace of Constantinople, which was an essential reference for medieval palatine architecture throughout the Mediterranean. One of its most important rooms was the Great Hall, built in the 6th century by Justinian II with a centralized floor plan, accessible from small alcoves around it and preceded by a narthex. ${ }^{7}$ Centuries later, the Roman imprint can still be seen in the floor plan of the Alhambra's Salón de Comares (Comares Hall), preceded by the Sala de la Barca. ${ }^{8}$

Andalusian references are likewise evident in the development of the monumental façades that presided over the great Castilian royal and noble palaces from the mid-14th century onwards. The typology, the ornaments, and the evolution of the exposed monumental text necessarily refer to Andalusian constructions. ${ }^{9}$ The importance attributed to external monumental writing in Roman and Islamic architectures is well documented. In Al-Andalus, since the Umayyad period, it was common to display extensive explanatory inscriptions on the façades and entrances of buildings, both religious and civic. Indeed, the Alhambra speaks to us through its inscriptions, which are written in the first person..$^{10}$ This monumental writing is continued, and profusely so, in $15^{\text {th-cen- }}$ tury Castilian palaces. In nearly every case, the self-propaganda of the patron

herencia de Al-Andalus, ed. Fátima Roldán (Sevilla, 2007), pp. 123-32; Rafael Cómez Ramos, "Las casas del infante don Fadrique y el convento de Santa Clara de Sevilla," Historia, Instituciones, Documentos 34 (2007), 95-116; Juan Carlos Ruiz Souza, "Toledo entre Europa y Al-Andalus en el siglo XIII: Revolución, tradición y asimilación de las formas artísticas en la Corona de Castilla," Journal of Medieval Iberian Studies 1/2 (2009), 256-65.

6 Juan Carlos Ruiz Souza, "El Palacio Especializado y la Génesis del Estado Moderno. Castilla y Al-Andalus en la Baja Edad Media", in La Ciudad Medieval: de la casa principal al palacio urbano, eds. Jean Passini, and Ramón Izquierdo Benito (Toledo, 2011), pp. 93-128. Jeffrey Michael Featherstone, "The Great Palace as Reflected in the De Cerimoniis," in Visualisierungen von Herrschaft, ed. Franz Alto Bauer, Byzas 5 (Istanbul, 2006), pp. 47-61, esp. 50-53. About the image of the Chrysotriclinos we have today, see: Jean Ebersolt, $L e$ Grand Palais de Constantinople et le Livre de Cérémonies (Paris, 1910), pp. 77-92. y aportaciones sobre la arquitectura palatina," Cuadernos de la Alhambra 40 (2004), 77102, esp. $78-83$.

9 Ruiz Souza, "Castilla y Al-Andalus", 27-32.

10 José Miguel Puerta Vílchez, Leer la Alhambra. Guía visual del monumento a través de sus inscripciones (Granada, 2010), pp. 69-73, 226-28. 
prevails, as a mark imprinted on the main access of the building he founded, looking almost like a triumphal arch. ${ }^{11}$

One century earlier, in the Nasrid world, the façades of all kinds of constructions underwent a great development. The madrasa of Yusuf $\mathrm{I}$, the maristan of Muhammad v, the façade of Comares, which was erected by the sultan himself in the courtyard of the Cuarto Dorado (Golden Room), and the great doors of the Alhambra's wall - all these 14th-century examples have monumental fronts with lengthy explanatory texts. The façades take on such an important role that they emerge, in themselves, as independent elements of the building. The same can be said for those of the palaces of Pedro I in Tordesillas and Seville. If the palace of Tordesillas praises the mythical victories of his father Alfonso XI, those in Seville refer to King Don Pedro as patron not of the palace but of the façade - as though the latter were an autonomous entity, a notion entailing an interesting qualitative leap.

\section{Façade, Square, and Elevated Throne Room. The Palace of Comares in the Alhambra and the Castilian Palaces of the Late Middle Ages}

A large façade works best when preceded by a large, more or less precisely delimited space, for the staging and contemplation of the king. Along with the appearance of the great façade we must therefore talk about the creation of the square before it.

First, we return to the palatine city of the Alhambra, where the issue of the southern side wall of the Palace of Comares - where the palace of Carlos v was erected in the first half of the 16th century - is yet to be resolved. We consider this space should be seen as fundamental to the conception of the square that accompanied the Castilian palaces of the late medieval period and as essential to expressing the intended image of the sultan. In fact, in another study we have speculated about the disposition of this whole area. ${ }^{12}$ We proposed that here was once a large space in front of the palace that served as a representational plaza - where the most important routes within the palatine city

11 Juan Carlos Ruiz Souza, "Fachadas parlantes. Escritura en la escenografía del poder," in Écritures du pouvoir - Les cultures politiques dans la péninsule Ibérique et au Maghreb, VIIIe - XVe siècles 2, ed. Véronique Lamazou-Duplan, Scripta Medieaevalia 38 (Bordeaux, 2019), pp. 181-94. Ruiz Souza, “Tipología, uso y función del Palacio de Comares," 77-102. 
converged - which would explain the later construction of the Renaissance palace of Carlos v there. ${ }^{13}$

We believe it is no coincidence that the Puerta del Vino (Wine Gate) (Figure. 14.2) was erected between the Puerta de la Justicia (Justice Gate) and the Nasrid palaces, as a sort of triumphal arch located at a strategic point of the city. We are talking about a great direct access door and not a bent entrance, unlike the monumental Nasrid doors that mark the walls of the palatine city, which have a formal and symbolic character instead of a defensive one. Although its rich painted decoration, of various colours, would emulate an ephemeral arch, it still preserves, on its eastern wall, the representation of a sebqa, invoking a large commemorative structure covered by, or made of, a large and sumptuous fabric. The coat of arms of the Banda de Muhammad v (Band of Muhammad v) appears in the rich ceramic decoration that garnishes the arch of the door facing the palaces. The exterior façade of the southern side of the Palace of Comares could thus be contemplated from the Puerta del Vino.

The southern wing of Comares Palace is the highest palatine structure of the preserved Nasrid architecture, being composed of three superposed bodies. In the highest one, a large arch can be seen. It would give way to a large hall whose ceiling would most probably be above the gallery that precedes it, so that the height of the southern side, according to our hypothesis, could be even higher than it currently is. It is common for arcaded galleries to precede a higher structure. It is true that the height of the terrain of the hill of the Alhambra rises southwards so that the height of the courtyard of Comares is at a much lower level than that of the exterior side, where the Palace of Charles v stands. The presence of this slope would explain the introduction of the intermediate body of the aforementioned wing. We believe that the Palace of Comares would have had an outward façade. What would then be the purpose of the location of a great royal hall so high in this part of the Palace of Comares? A great royal hall, the existence of which we cannot doubt because both its monumental access door and part of its interior decoration have been preserved. ${ }^{14}$

We think that a great palace like Comares would have had a great contemporary façade; since the one known today with that name, located between the palace and the mexuar (Islamic room for justice), was subsequently built, in 1369, according to its inscription, which refers to the conquest of Algeciras by the Nasrid troops. ${ }^{15}$ Monumental spaces dominating interior courtyards

\footnotetext{
13 Antonio Gámiz Gordo, La Alhambra nazarí. Apuntes sobre su paisaje y arquitectura (Sevilla, 2001), pp. 53-57, 167-85.

14 Ruiz Souza, "Tipología, uso y función del Palacio de Comares," pp. 83-86.

15 Puerta Vílchez, Leer la Alhambra, pp. 69-73.
} 
exist in other palatine cities of Al-Andalus, like the great portico of Madinat al-Zahra. ${ }^{16}$ But the main reason behind our approach lies in the studies of the Castilian royal palaces in Tordesillas and the Alcazar of Seville. These two buildings share a square dominated by a palatine façade bearing inscriptions and heraldry.

\section{Pedro I's Palaces and the 14th Century in Castile: Tordesillas and the Alcazars of Seville and Carmona. Oh, place where the heroic king manifests!}

In Tordesillas, the medieval roads of the town are preserved. The narrow street of Alonso Castillo Solórzano still runs parallel to the Duero River and comes across a medieval brick door within a pointed arch. The door opens into a sort of corridor, which in turn leads to a square, today the atrium of the convent of Santa Clara (Figure. 14.3). The square is dominated by the palace façade, which is still preserved. The façade appears now mutilated because it would originally have been much larger, as evidenced by the remains preserved at its pinnacle. ${ }^{17}$ The construction of the choir and the antechoir of the convent church altered that whole part of Pedro I's palace, explaining why only the front part remains. ${ }^{18}$ In the latter we see two tablets featuring partially preserved texts, which refer to the great victory of the Castilians over the Marinids of Fez in the Strait of Gibraltar, during the Batalla del Salado (Battle of Salado). In Tordesillas we can only find texts on the façade, as the heraldry has not been preserved.

In the case of Seville, an imposing triumphal arch was constructed at the entrance to the Patio de la Montería (Montería Courtyard), next to the current Sala de la Justicia. Although the three archways' heraldic decoration is very deteriorated, what appears to be the badge of the Orden de la Banda (Knights of the Band) can be seen in its central part, which most probably was originally complemented with coats of arms displaying lions and castles. The preserved remains also suggest that some kind of elevation might have existed on

16 Ruiz Souza, “Tipología, uso y función del Palacio de Comares," pp. 83-86.

17 Juan Carlos Ruiz Souza, "Santa Clara de Tordesillas. Restos de dos palacios contrapuestos (siglos XIII-XIV)," in Actas del V Congreso de Arqueología Medieval Española, Valladolid 19991 (Valladolid 20o1), pp. 851-6o.

18 Juan Carlos Ruiz Souza, "La Iglesia de Santa Clara de Tordesillas. Nuevas consideraciones para su estudio," Reales Sitios 36/140 (1999), 2-13. 
top of the arch. ${ }^{19}$ The latter opens onto the square dominated by the majestic façade of the Palacio de la Montería (Montería Palace) (Figure. 14.4), where we find heraldic decorations, a laudatory text of the ruler dating from 1364, and an elevated hall, or qubba. ${ }^{20}$ Seen from the inside, the elevated structure has one peculiarity: between the hall itself and the exterior façade, there still is a rich muqarnas vault. From the latter's special location, we can infer that it was meant to guide the beholder's contemplation of the ruler as the latter looked out onto the Plaza de la Montería (Montería Square). The royal and religious connotations of muqarnas vaults are clear, as demonstrated by many studies and evidenced by the places where they have been found. ${ }^{21}$ The arcade that visually connects this location to the square at its feet is not a window but an open gallery or balcony, at which the king, Pedro I, could be seen standing, right beneath the inscription mentioned above, a deictic element referring to the monarch himself. ${ }^{22}$

The remains of the Carmona Palace, where the treasure of Pedro I was relocated during the final stages of his reign and where his family members and most loyal subjects resided after his death in 1369 , are less well known. ${ }^{23}$ The monumental entry of the Alcazar is still preserved, as well as remains of its interior pictorial decoration, in which we again observe the badge used by Pedro I in clear reference to the Orden de la Banda founded by his father, Alfonso XI.

We believe that Pedro I was copying Andalusian models in Tordesillas and Seville. The most important palace being built in Granada during the central decades of the 14th century, contemporary with the palaces of Tordesillas and Seville, was that of Comares. We thus find in Castile a reflection of what could be seen in the Alhambra, with the formal vocabulary of the two Castilian façades clearly referring to the Nasrid world.

19 Antonio Almagro Gorbea, "La recuperación del jardín medieval del Patio de las Doncellas," Apuntes del Alcázar 6 (2005), 45-67, esp. 62; Miguel Ángel Tabales Rodríguez, "Investigaciones arqueológicas en la Portada de la Montería del Alcázar de Sevilla," Apuntes del Alcázar de Sevilla 7 (2006), 6-39, esp. 24-29.

20 Julie Marquer, "El poder escrito: problemáticas y significación de las inscripciones árabes de los palacios de Pedro I de Castilla (1350-1369)," in Palacio y Génesis del Estado Moderno en los Reinos Hispanos. VI Jornadas Complutenses de Arte Medieval, eds. Pilar Martínez Taboada, Elena Paulino Montero, and Juan Carlos Ruiz Souza, Anales de Historia del Arte 23/2 (2013), pp. 499-508.

21 Juan Carlos Ruiz Souza, "La cúpula de mocárabes y el Palacio de los Leones de la Alhambra," Anuario del Departamento de Historia y Teoría del Arte 12 (2000), 9-24.

22 To understand how this royal palace works, see: La planimetría del Alcázar de Sevilla, ed. Antonio Almagro Gorbea (Granada, 200o).

23 Antonio Almagro Gorbea, "Los palacios de Pedro I. La arquitectura al servicio del poder," in Palacio y Génesis, eds. Martínez Taboada et al., pp. 25-49, esp. 35-38. 
The above context may illuminate the initial verse of Ibn Zamrak's great poem from the mid-14th century, which dominated the lower part of the southern wing of the Nasrid palace: "Oh, place where the heroic king manifests!"24 We believe that this verse explains the function of the southern wing of the palace, that is, to present the majesty of the Nasrid sovereign to his subjects. This should be probably understood as the survival of former ideas rooted in the visual culture of power in the Mediterranean context, such as: the window of appearances (the place, window, or gallery through which the sovereign could be seen from the outside by his subjects), which already existed in Ancient Egypt; ${ }^{25}$ the monumental structures erected in the upper part of the façade of the Umayyad castles-palaces in the Syrian-Jordan desert during the 7 th and 8th centuries or, later, in Abbasid Samarra; ${ }^{26}$ the qubba that crowned the great portico of Madinat al-Zahra from the 1oth century, from which the caliph would present himself to the troops; ${ }^{27}$ or the great monumental architecture built as a large palace at the entrance to the Ayyubid citadel of Aleppo, during the Mamluk period, between the 13th and 14th centuries. ${ }^{28}$ All of this leads us to raise the following hypothesis: that during the mid-14th century, between the Nasrid Emirate of Granada of Muhammad v and the Castilian court of Pedro I, the forms of representation of royal authority were redefined; throughout the 15th century, these forms were not forgotten but rather continuously repeated.

\section{$5 \quad$ The 15th Century: The Alcazar of Segovia and the Noble Palaces}

During the first half of the 15th century, a big opening with Moorish decorations, and from which the king could be seen, was built on the east side of the

\footnotetext{
24 Puerta Vílchez, Leer la Alhambra, p. 85.

25 Palace of Ramses III in Medinet-Habu (Thebes, Egypt).

26 Qasr al-Hayr al Gharbi, Jirbat al-Mafyar, etc. Oleg Grabar, Ceremonial and Art at the Umayyad Court (Princeton University, 1955), pp. 128-40; Patricia Carlier, and Frederic Morin, "Recherches achéologiques au château de Qastal (Jordanie)," Annual of the Department of Antiquities 28 (1984), 343-83; Gulru Necipoglu, "An outline of shifting paradigms in the palatial architecture of the pre-modern Islamic world," Ars Orientalis 23 (1993), 3-24, esp. 10-11; Jonathan M. Bloom, "The Qubbat al-Khadra' and the iconolography of Height in Eartly Islamic Architecture," Ars Orientalis 23 (1993), 135-42; Alastair Northedge, "An interpretation of the Palace of the Caliph at Samarra (Dar al-Khilafa or Jawsaq al-Khaqani)," Ars Orientalis 23 (1993), 143-70.

27 Almagro, Antonio, "Conjunto Arqueológico de Madinat al-Zahra (Córdoba). Pórtico Oriental. Alzado general restituido," in Arquitectura en Al-Andalus. Documentos para el siglo XXI , ed. Alfonso Jiménez (Barcelona, 1996), pp. 214-15.

28 Yasser Tabbaa, "Circles of power: palace, citadel and city in ayyubid Aleppo," Ars Orientalis 23 (1993), 143-70.
} 
great entrance tower of the Alcazar de Segovia, known as the Tower of Juan II. ${ }^{29}$ While it has since been filled by a Gothic-style double window (Figure. 14.5), originally it was a single larger opening that reached the level of the floor, as the two preserved jambs show. This meant that the king was visible in full length. Intense restoration of the site has revealed another horseshoe arch, at the same level and with the same royal and visual meaning, on the south side of the Tower of Juan II.

During the Middle Ages, some sort of triumphal arch with heraldic decoration probably served as an entrance to the great Alcazar, on its south-eastern corner beyond the moat. Nowadays, that entrance has a different appearance, due to the renovations made by the Habsburgs in that area during the 16th century. ${ }^{30}$

The great mid-15th-century castle of the Fonseca family in Coca (Segovia) has been preserved. In this case, the nobility seemed to copy the models defined by the monarchy. Its external appearance, with its richly plastered and painted walls simulating a great theatrical and ephemeral fabric construction, makes it unique and exceptional among the preserved civic heritage from that period in Castile. ${ }^{31}$ The fortress has two external entrances. The eastern or main one is a monumental access with two towers as well as a decorative brick arch flanked by coats of arms, which in turn leads to an inner square. In the body of the castle, a great elevated section, again, has been thoroughly preserved. In its inner part we can still see a vault with Gothic ribs painted and simulated, that enabled the lord of the fortress to make himself visible. The western and southern façades preserve some windows, but the spectacular character of the main entrance is undoubtedly higher. In addition, that is where the inner space, or square, delineated by the external wall of the castle and the internal body of the fortress, has the largest dimensions.

The castle-palace of Belmonte, property of the Pacheco family, the marquises of Villena, was built around the same time. Despite the restorations made in the 19th century by Eugenia de Montijo, most of its medieval structure survives. The original main entrance can still be seen, though it is currently disabled. That access, with a southwest orientation, faces the village and opens

29 On the mentioned 'Torre de Juan II' in the Alcázar of Segóvia, see: Juan Antonio Ruiz Hernando, "El Alcázar de Segovia, desde los orígenes al siglo XV," in El Alcázar de Segovia. Bicentenario 1808-2008, ed. Patronato de El Alcázar de Segovia (Segovia, 2010), pp. 45-91, esp. 70 .

30 José Miguel Merino de Cáceres, "El Alcázar de los Austrias," in El Alcázar de Segovia, pp. $115-47$, esp. 138.

31 Carmen Rallo Gruss, "El Castillo de Coca y su ornamentación," Anales de Historia del Arte 6 (1996), 13-34. 
into one of the fortified towers of the fortress walls. Another characteristic of that entrance that can still be observed is the heraldry of Juan Pacheco: a shell that undoubtedly refers to the Orden de Santiago (Order of Santiago), in which the marquis held the position of master from 1467 until his death in 1474, during the reign of Enrique IV. On that same door, but within the body of the castle and once crossed the parapet walk, there is another great section that connects to the main hall of the palace and from which the marquis could lean out.

In the late 15th century, the castle-palace of the Mendoza family, in Manzanares el Real, repeated exactly the same formula as in Coca. Its main monumental entrance, with the coat of arms at the keystone of its arch, leads into the castle, and in its central upper part another great medieval section connects directly with the upper gallery of the castle's courtyard.

In the same years, we find an identical kind of structure adopting late Gothic forms. In Ayllón in the late 15th century, Juan de Contreras built a majestic palace next to the wall enclosing the city. Framed by an alfiz (an Islamic decorative rectangular moulding), the great façade displays large coats of arms and an inscription that refers to the patron and to the Catholic monarchs and mentions the date 1497. In a narrow space between the wall's front and the palace façade, a small triumphal arch was erected and decorated with the heraldry of the lords of the village; it was renovated in the 16th century, when the coat of arms of the marquises of Villena was inserted. This arch can be considered the true starting point for the typology of the square dominated by the abovementioned monumental façade. It is rather remarkable that the heraldry was inserted on the inner arch and not on the external door of the wall itself. Many of the great Castilian palaces of the 15th century probably already had analogous preceding spaces, or courtyards, identified with a triumphal structure.

The insertion of the courtyard preceding the palace had been a commonplace practice since the late 14th century in the Hispanic world, as can be seen in the old palace of Olite. There, Carlos III bought some houses with the intention of demolishing them to open up an empty space at the feet of the old palace, in keeping with uses already established in 14th-century Castile. From the elevated hall that led to the square, the Navarrese monarch could make himself visible. Surely, the intervention of Queen Leonor, originally from Castile and employing her own master builder, facilitated the introduction of Castilian models to the palatine-construction policy of the Navarrese monarchy. ${ }^{32}$

32 Javier Martínez de Aguirre, Arte y monarquía en Navarra 1328-1425 (Pamplona, 1987), pp. 143, 146 . 


\section{The Rey en Siella. Multi-functional Spaces and Settings for King's Images}

Every palace or important house included a throne room - called 'rey en siella' $^{\prime 33}$ (king seating on the throne), as stated in written sources. It was in this distinctively multi-functional room that political events and ceremonies, such as the reception of ambassadors and other personalities; feasts; and literary, musical, and magic performances took place. It was a chameleonic space that, depending on its decoration, variously consisting of fabrics, tapestries, and tableware, could be made suitable for the shifting needs of each moment. ${ }^{34}$

The Libro del Caballero Zifar (Book of the Knight Zifar) perfectly illustrates the space I am describing, referring to the palace of the Dueña del Lago (Lady of the Lake), where stands were located at varying heights on the occasion of receptions for the kingdom's nobles. After the official audience, a meal was served with lavish tableware and even more lavish delicacies. Then, minstrels, magicians, and musicians made their entrance. ${ }^{35}$ Examples of this include the Salón de Embajadores (Ambassadors' Hall) of the Palace of Comares in the Alhambra, with its centralized floor plan and nine surrounding alcoves; the Salón de Tinell (Tinell's Hall) (Figure. 14.6) of the royal palace of Barcelona, with a rectangular floor plan; and the Cuarto del Almirante (Room of the Admiral) of the Alcazar of Seville, more consistent with Andalusian types. ${ }^{36}$ The nobility would, thereafter, repeat these monarchical models.

\section{$7 \quad$ Other Court Spaces of Knowledge and Literature. Towards the Prince's Hall of Virtue? Adab and Mầlis}

... and I had a great and beautiful palace made and wrote on the walls all of the knowledge that I ought to show and learn: all the stars and all the figures and all the things. ${ }^{37}$

33 We find this expression several times in the 14th-century Poema de Alfonso Onceno, for instance, in verse 6o: Real caballero en siella (the king sitting on the throne). Poema de Alfonso Onceno, ed. Juan Victorio (Madrid, 1991), p. 155.

34 Olga Pérez Monzón, “'Ornado de tapicerías y aparadores de muchas vaxillas de oro e plata'. Magnificencia y poder en la arquitectura bajomedieval castellana," in Palacio y Génesis, eds. Martínez Taboada et al., pp. 259-85.

35 Libro del Caballero Zifar, ed. Joaquín González Muela (Madrid, 199o), pp. 216-18.

36 For a broad repertoire, see: Antonio Almagro Gorbea, Palacios medievales hispanos (Madrid, 2008).

Sendebar, ed. María Jesús Lacarra (Madrid, 2007), pp. 72-73. 
This quote from the interesting work Sendebar, which the prince Don Fadrique had translated from Arabic in 1253, refers to the construction of a palace for the education of the prince, a residence where he could study in undisturbed isolation. ${ }^{38}$ This is not the only piece of literature alluding to the construction of architectural spaces tailored to the cultivation of knowledge and education as well as meetings among wise men; indeed, this was a very common theme in the mirror of princes literary genre, one clearly demonstrating the nobility's attempts to shape themselves in the king's image. ${ }^{39}$

In this respect, contemporary prose provides much information about court life and its idealized representation. This is exactly where, in our opinion, the prince's hall of virtue appears to have born. In the words of Gómez Redondo:

The analysis of medieval literary fiction must draw from two preliminary considerations: 1) fiction is a narrative process that entails the discovery of a series of real images, first invented and subsequently imitated; 2) for this reason, fiction constitutes the safest means to discover both the reality and the various relationships that the individual maintains with it ... fiction articulates communication mechanisms that enable the human being to acquire specific features of identity ... ${ }^{40}$

These properties of fiction allowed for the creation of a new image of the king $^{41}$ and, relatedly, the emergence of literary spaces in which his courtly

38 See the introduction by María Jesús Lacarra in: Sendebar, pp. 37-41. She reminds us of important medieval texts on this subject.

39 Regarding this cultural context, see: La Literatura en la época de Sancho IV, Actas del Congreso Internacional, Alcalá de Henares 21-24 de febrero de 1994, eds. Carlos Alvar, and José Manuel Lucía Megias (Alcalá de Henares, 1996); Fernando Gómez Redondo, El desarrollo de los géneros. La ficción caballeresca y el orden religioso (Madrid, 1999), pp. 1225770; Rosa María Rodríguez Porto, "María de Molina y la Educación de Alfonso XI: la 'Semblanzas de Reyes' del Ms. 7415 de la Biblioteca Nacional," Quintana 5 (2006), 219-31.

40 Fernando Gómez Redondo, Historia de la prosa medieval castellana. II El desarrollo de los géneros. La ficción caballeresca y el orden religioso (Madrid, 1999), p. 1315.

41 Olga Pérez Monzón has published many important works on this subject; see, for instance: Olga Pérez Monzón, "Iconografía y poder real en Castilla. Las imágenes de Alfonso VIII," Anuario del Departamento de Historia y Teoría del Arte 16 (2002), 19-41; Olga Pérez Monzón, "La dimensión artística de las relaciones de conflicto," in La monarquía como conflicto en la Corona castellano-leonesa (c. 1230-1504), ed. José Manuel Nieto Soria (Madrid, 2006), pp. 547-62o; Olga Pérez Monzón, "Quando rey perdemos nunq[u]a bien nos fallamos. La muerte del rey en la Castilla del siglo XIII," Archivo Español de Arte, 80/ 320 (2007), 379-94; Olga Pérez Monzón, "Heráldica versus imagen," in Alfonso X el Sabio, ed. Isidro G. Bango Torviso (Murcia, 2009), pp. 94-101; Olga Pérez Monzón, “Ceremonias 
qualities could be performed. Moreover, such texts place an emphasis on the ideal knowledge and virtues of the knight. At this point, we should introduce the Islamic notion of $a d a b$, studied by Susana Calvo Capilla, ${ }^{42}$ which can be understood as the body of knowledge and virtues that every good ruler or lord should have. More broadly, an important role is played by the maŷlis, i.e. meetings of wise men, literary figures, and teachers, all chaired by the ruler. But this was not a new practice: as Cynthia Robinson has pointed out, the Casa del Regocijo (House of Joy), commonly known as the Aljaferia, may have hosted such literary meetings at the Taifa court of Zaragoza in the 11th century. ${ }^{43}$

In this context, we are now able to understand that, alongside history, science and justice, gambling, hunting and, of course, the rich literary world in its entirety, had their significance too. In this period, literature seeks to secure victory in a fictitious reality full of adversities (fantastic journeys, fighting supernatural beings, tournaments in the tradition of courtly love) by recreating, in its own way, intellectually and physically, the battle and the victory, which before seemed to be confined to the battlefield.

\section{Literature and History: The Palace of the Lions in the Alhambra, Palace of the Montería in the Alcazar of Seville, the Alcázar of Segovia, the Infantado Palace of Guadalajara, and the Castle of Belmonte}

The literary context offered in the previous section allows for a better understanding of the Palacio de los Leones (Palace of the Lions) in the Alhambra (Figure. 14.7) and the Palacio de la Montería (Palace of the Montería) in the Alcazar of Seville. We have addressed the functional character of the Nasrid palace in previous studies, and we will now revisit it. Among the three painted

regias en la Castilla Medieval. A propósito del llamado 'Libro de la Coronación de los Reyes de Castilla y Aragón'," Archivo Español de Arte 83/332 (2010), 317-34.

Susana Calvo Capilla, "Ciencia y adab en el islam. Los espacios palatinos dedicados al saber," in Palacio y Génesis, eds. Martínez Taboada et al., pp. 51-78; Susana Calvo Capilla, "Images and Knowledge of Classical Antiquity in the Palace of Madinat al-Zahra' (Cordoba, 1oth century): Its Role in the Construction of the Caliphal Legitimacy," Muqarnas 31 (2014), 1-33; Susana Calvo Capilla, "Espacios de conocimiento en el Islam: Mezquitas, Casas de Sabiduría y Madrasas," in Domus Hispanica. El Real Colegio de España y el Cardenal Albornoz en la Historia del Arte, ed. Manuel Parada López de Corselas (Bolonia, 2018), pp. 179-94.

43 Cynthia Robinson, In praise of song. The Making of Courtly Culture in al-Andalus and Provence, $1005^{-1134}$ A.D. (Leiden, 2002). 
domes in the King's Hall or Hall of Justice, to the east of the Palace of the Lions, the outer ones display scenes inspired by literature, whereas the central vault shows figures engaged in conversation (Figure. 14.8). ${ }^{44}$ Because the coat of arms of the king appears in small dimensions beneath each of these figures and, on a larger scale, at either end of the oblong composition, this is likely a maŷlis scene of Muhammad $v$ with his wise men. ${ }^{45}$ In the Sevillian example, on the other hand, the first thing that captures our attention are the references to history in the repurposed Roman, Visigothic, and Umayyad materials ${ }^{46}$ of the King's Gallery of the Salón de Embajadores (Hall of Ambassadors) and the references to literature in the scenes within the medallions of the northern and southern rooms of the Hall of Ambassadors, some of which have to do with the Libro del Caballero Zifar. ${ }^{47}$

With its iconographic references to history and literature, the Sala de los Reyes (Room of the Kings) in the Alcazar of Segovia operated along the same lines. Though its origin dates back to the second half of the 13th century, there is no doubt about Henry IV's involvement in both its conception and final form. ${ }^{48}$ The room features a gallery displaying the seated rulers of Castile and

44 Courting The Alhambra. Cross-disciplinary approaches to the Hall of Justice Ceiling, eds. Cynthia Robinson, and Simone Pinet (Special offprint of Medieval Encounters) 14/2-3 (Leiden, 2008).

45 Juan Carlos Ruiz Souza, "El palacio de los Leones de la Alhambra: ¿Madrasa, Zâwiya yTumba de Muhammad V?," Al-Qantara 22/1 (2001), 77-120; Juan Carlos Ruiz Souza, "El Palacio de los Leones. Al-riyāọ al-sa'îd, el Jardín Feliz del Conocimiento," in Domus Hispanica: el Real Colegio de España en la historia del arte (1364-2014), ed. Manuel Parada López de Corselas (Bolonia, 2017), pp. 195-210; Juan Carlos Ruiz Souza, "El Palacio de los Leones de la Alhambra: Espacio de Virtud del Príncipe," in The Power of Symbols: The Alhambra in a Global Context, eds. Francine Giese, and Ariane Varela (Berlin, 2018), pp. 79-92.

46 Juan Carlos Ruiz Souza, "Rodrigo Jiménez de Rada, Alfonso X y Pedro I ante las 'reliquias arquitectónicas' del pasado en la construcción de la identidad de España. Historicismos antiguos," in Reyes y prelados: la creación artística en los reinos de León y Castilla (10501500), eds. María Dolores Teijeira Pablos, María Victoria Herráez Ortega, and María Concepción Cosmen Alonso (Madrid, 2014), pp. 219-30.

47 Juan Carlos Ruiz Souza, "El Palacio de la Montería del Alcázar de Sevilla. Contrapunto y futuro en el tardogótico," in 1514. Arquitectos tardogóticos en la encrucijada, eds. Begoña Alonso Ruiz, and Juan Clemente Rodríguez Estévez (Sevilla, 2016), pp. 319-37, esp. 329.

48 Miguel Ángel Castillo Oreja, "Imagen del rey, símbolos de la monarquía y divisas de los reinos: de las series de linajes de la Baja Edad Media a las galerías de retratos del Renacimiento," in Galería de Reyes y de Damas del Salón de Embajadores, Alcázar de Sevilla, ed. Miguel Ángel Castillo Oreja (Madrid, 2002), pp. 1-39; David Nogales Rincón, "Las series iconográficas de la realeza castellano-leonesa (siglos XII-XV)," En la España Medieval 1 (2006), 81-112, esp. 83-86; Ignacio Hernández, "El Alcázar en tiempos de la dinastía trastámara," in El Alcázar de Segovia, pp. 95-112, esp. 104; David Chao, Iconografía regia en la Castilla de los Trastámara (Universidad de Santiago de Compostela, 2005). 
León, among whom we find the legendary figure of El Cid. The programme of the Sala de los Reyes evokes the past as a source of political legitimacy. This differs from the same Alcazar's solemn Salón del Solio (Hall of the Throne), intended as a throne room (Figure. 14.9) in keeping with the qubba tradition in which the ruling king exhibited himself 'en siella' (seated).

The Salón de Linajes (Hall of Lineage), along with the halls of Salvajes (Savages), Cazadores (Hunters) and Consejos (Council), in the Palacio del Infantado of Guadalajara, a property of the Mendoza family built in the late 15th century, should be interpreted through this same lens, given their same references inspired by history and literature. ${ }^{49}$

We turn now to the square plant room of the castle-palace of Belmonte, known as a chapel but, in our view, intended for a very different purpose. The lower register of its wooden dome displays themes that refer, once again, to the rich tradition of mid-15th-century courtly literature: a knight and a lady playing chess, hunting scenes, a scene involving a unicorn, and other themes all of which refer again to the rich tradition of mid-15th century courtly literature. The two splayed windows are embellished with vegetal motifs, including coats of arms and fantastic animals. The vegetal ornaments continue around the dome of the room, seeking to evoke a natural yet fantastic space. ${ }^{50}$

The room in the castle-palace of Belmonte can be seen from the exterior through the octagonal tower on its top. It communicates with the main hall of the palace, where the above-mentioned palace section, through which the marquis made himself visible, is located. Moreover, and certainly due to its literary associations, it is connected to a small, well-protected room in a tower, which was probably meant to house books and documents. In fact, despite the lack of any corroborating evidence, this would have been the ideal location for storing the marquis of Villena's 'treasure,' including books and documents, along with other valuable objects - and this function is all the more likely given the room's connection to such a 'literary' space as the square plant room of the castle.

In sum, we believe that all the evidence presented here attests to the origins of the so-called prince's halls of virtue, which would become very common in the modern age and in which we find a combined emphasis upon a prince's victory on the battlefield and his historical lineage, among other aspects of his prestige.

49 Francisco Layna Serrano, El Palacio del Infantado en Guadalajara (Guadalajara, 1997).

50 Miguel Salas Parrilla, El Castillo de Belmonte (Madrid, 2010), pp. 32-41. 
We would now like to turn to the elevated galleries, known as andamios during the Middle Ages, which were closely linked with the literary world invoked in the previous section. ${ }^{51}$ In both the castle of Coca (Segovia) and the castle of Manzanares (Madrid), we find at the highest part of the building a gallery, which probably served as a position from which to view the land outside the castle, where jousts, tournaments, and other kinds of events would have taken place (Figure. 14.10).

These galleries were not built for temperature-control purposes: while the gallery is located on the southern side in the case of Manzanares, in Coca it occupies the northern wing of the castle, as it likewise does in the castle of the Álvarez de Toledo family in Oropesa (Toledo). In addition, the andamios rarely coincide with the area of the main access to the castle, though this can be found in the Palacio del Infantado in Guadalajara, where the andamios are located on the entrance façade of the building. From the andamio of Coca Castle, an artificial scene can be enjoyed, framed by the moat that surrounds the castle and the slope coming from it.

The andamios at Coca and at Manzanares have a distinct balcony at their centres, probably reserved for the lord of the palace. We believe that the high gallery preserved in the top floor of the southern side of the Palacio de la Montería in the Alcazar of Seville, built in the late 15th century under the rule of the Catholic monarchs, may have had a function similar to that of the andamios, considering its rich heraldic decoration based on the repetition of the joke-and-arrows badge.

\section{Forms and Messages without Frontiers in a Shared Cultural Context. Egypt, Venice, Al-Andalus, Castile, and Naples}

Obviously, Castile and Granada are no exceptions within the larger Mediterranean world. For example, the spectacular nature of the great gates of

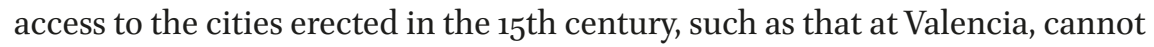
be overlooked. ${ }^{52}$ However, to observe the continuity of spectacular elements rooted in antiquity and bearing witness to a shared visual culture of power, we

$5^{1} \quad$ Libro del Caballero Zifar, p. 92.

$5^{2}$ Amadeo Serra Desfilis, "Promotores, tradiciones e innovación en la arquitectura valenciana del siglo XV," Goya 334 (2011), 58-73. 
must go beyond the Iberian Peninsula, to Cairo, Naples, or Venice. Indeed, this wider region was connected by merchants and clear economic interests.

For example, the Doge's Palace in Venice was built in such a way as to establish a visual dialogue with the great iwan of Cairo, a Mamluk structure from the 14th century. ${ }^{53}$ In the same period, the great tower of Comares was being erected in the Alhambra, as an architectural marker of the palatine city. It, too, was probably inspired by the image of power of the great iwan al-Nasir from the Mamluk period in Cairo, ${ }^{54}$ the undisputed capital of the Mediterranean in the late Middle Ages.

Equally important is the great palace-fortress of Castelnuovo in Naples..$^{55}$ The main entrance to the palace features a large triumphal arch, with rich decoration in relief narrating the arrival to the city of King Alfonso el Magnánimo (Alfonso the Magnanimous) in 1443 (Figure. 14.11). ${ }^{56}$ The tribune for the presentation of the ruler is located directly above. In contrast to the façade of the Montería in Seville, here the monarch appears not only above an inscription referring to him but also above an image of him in relief. Inside, the large Sala dei Baroni (Hall of the Barons), built by the Majorcan Guillem Sagrera, would serve as the great throne room. This space is conceived in Gothic forms as a Castilian qubba (square plan and domed) (Figure. 14.12). We should recall that Alfonso was born in the royal palace of Medina del Campo (Valladolid), where there was also a qubba. As the son of Fernando de Antequera and grandson of Juan I of Castile, he belonged to the Trastámara dynasty, the royal family of Castile, and he used art with a clear political sense. All of these works were the result of the reforms conducted by Alfonso the Magnanimous between 1442 and $1458 .{ }^{57}$ Other examples can be found among the palatine constructions in

53 Deborah Howard, "Venise et le Mamlûks," in Venise et l'Orient, ed. Stefano Carboni (Paris, 2006), pp. 72-89.

54 Doris Behrens-Abouseif, "The Citadel of Cairo: stage for mamluk ceremonial," Annales Islamologiques 24 (1988) 25-79, esp. 34-45; Nasser Rabbat, The Citadel of Cairo. A new interpretation of royal mamluk architecture (Leiden, 1995), pp. 244-25o; Doris BehrensAbouseif, Cairo of the Mamluks. A History of the Architecture and its Culture (London, 2007), pp. 175-78; Nasser Rabbat, Mamluk History through architecture. Monuments, Culture and Politics in Medieval Egypt and Syria (Cairo, 2010), pp. 157-65.

55 Rosa Chilà, "Castelnuovo, forteresse et résidence d'Alphonse le Magnanime a Naples" in Palacio y Génesis, eds. Martínez Taboada et al., pp. 431-44.

56 Christoph Luitpold Frommel, "Alberti e la porta trionfale de Castel Nuovo a Napoli," Annali di architecttura 20 (2008), 13-36.

57 Enrico di Nicola, "Arquitectura del siglo XV en Campania," in Una arquitectura gótica mediterránea 2, ed. Arturo Zaragozá Catalán (Valencia, 2003), pp. 99-114; Joan Domenge i Mesquida, "La gran sala de Castelnuovo. Memoria del Alphonsis regis triumphus," in 
France, such as the castle-palace of Vincennes ${ }^{58}$ or the Palace of the Popes in Avignon. 59

Finally, it is also important to go beyond the cold and naked architectural spaces. Our interpretation would not be complete without an understanding of the use of rich fabrics to cover the walls of the most important halls, which would allow them to change as needed, just like a person changes clothing. This practice was incredibly developed in late medieval Al-Andalus, where the most precious silks served as a source of inspiration for amazing plasterworks that can still be seen in the palaces of the Alhambra.

This article has shown a distinctive concept of royal portraiture and its iconology by investigating the architectural and spatial framing of the real king during the period of the de facto genesis of the modern state in Castile, between the 14th and 15th centuries. The research revealed al-Andalus and its architectures to be important sources for the Crown of Castile and León, spanning east and west, past and present, and working across religious and historiographic frontiers. We have considered royal palaces, façades, and courtyards, among other specialized spaces and stages in and on which the new image of the king was shaped and expressed through architecture. To study these specialized settings is to study the image of the king's power and wisdom as well as related notions of his authority over history, over the present, and over the future. Irrespective of his real presence, he - meaning, his authority or political body - was always present in these palaces. In conjunction, we must also consider the new audiences that emerged in medieval society between the 13th and the $15^{\text {th }}$ centuries. The new king needed for his political project a new nobility, an emerging bourgeoisie, professional officers, and a standing army. All of these shaped a new society and became new audiences for a new royal portrait.

Le usate leggiadrie. I cortei, le cerimonie, le feste e il costume nel Mediterraneo tra il XV e XVI secolo, Atti del convegno-Napoli, 14-16 dicembre 2006, ed. Gemma Teresa Colesanti (Montella 2010), pp. 290-338.

58 Jean Chapelot, "L'Hôtel du Roi á Vincennes: Charles V dans son logis," in La cour $d u$ prince. Cour de France, cours d'Europe, XII ${ }^{-}-X V^{e}$ siècle, eds. Murielle Gaude-Ferragu, Bruno Laurioux, and Jacques Paviot (Paris, 2011), pp. 145-76. Dominique Vingtain, Avignon. Le Palais des Papes (Auxerre, 1998). 


\section{Bibliography}

\section{Secondary Sources}

Alfonso X, Las Siete Partidas, Glosadas por el licenciado Gregorio López del Consejo Real de Indias de su Magestad, Salamanca 1555 1 (Edición facsimilar Madrid, 1985).

Almagro, Antonio, “Conjunto Arqueológico de Madinat al-Zahra (Córdoba). Pórtico Oriental. Alzado general restituido," in Arquitectura en Al-Andalus. Documentos para el siglo XXI , ed. Alfonso Jiménez (Barcelona, 1996), pp. 214-15.

Almagro Gorbea, Antonio, "La recuperación del jardín medieval del Patio de las Doncellas," Apuntes del Alcázar 6 (2005), 45-67.

Almagro Gorbea, Antonio, Palacios medievales hispanos (Madrid, 2008).

Almagro Gorbea, Antonio, "Los palacios de Pedro I. La arquitectura al servicio del poder," in Palacio y Génesis del Estado Moderno en los Reinos Hispanos. VIJornadas Complutenses de Arte Medieval, eds. Pilar Martínez Taboada, Elena Paulino Montero, and Juan Carlos Ruiz Souza, Anales de Historia del Arte 23/2 (2013), pp. 25-49.

Behrens-Abouseif, Doris, "The Citadel of Cairo: stage for mamluk ceremonial," Annales Islamologiques 24 (1988) 25-79.

Behrens-Abouseif, Doris, Cairo of the Mamluks. A History of the Architecture and its Culture (London, 2007).

Bloom, Jonathan M., "The Qubbat al-Khadra' and the iconolography of Height in Eartly Islamic Architecture," Ars Orientalis 23 (1993), 135-42.

Calvo Capilla, Susana, "Ciencia y adab en el islam. Los espacios palatinos dedicados al saber," in Palacio y Génesis del Estado Moderno en los Reinos Hispanos. VIJornadas Complutenses de Arte Medieval, eds. Pilar Martínez Taboada, Elena Paulino Montero, and Juan Carlos Ruiz Souza, Anales de Historia del Arte 23/2 (2013), pp. 51-78.

Calvo Capilla, Susana, "Images and Knowledge of Classical Antiquity in the Palace of Madinat al-Zahra' (Cordoba, 1oth century): Its Role in the Construction of the Caliphal Legitimacy," Muqarnas 31 (2014), 1-33.

Calvo Capilla, Susana, "Espacios de conocimiento en el Islam: Mezquitas, Casas de Sabiduría y Madrasas," in Domus Hispanica. El Real Colegio de España y el Cardenal Albornoz en la Historia del Arte, ed. Manuel Parada López de Corselas (Bolonia, 2018), pp. 179-94.

Carlier, Patricia, and Morin, Frederic, "Recherches achéologiques au château de Qastal (Jordanie)," Annual of the Department of Antiquities 28 (1984), 343-83.

Castillo Oreja, Miguel Ángel, "Imagen del rey, símbolos de la monarquía y divisas de los reinos: de las series de linajes de la Baja Edad Media a las galerías de retratos del Renacimiento," in Galería de Reyes y de Damas del Salón de Embajadores, Alcázar de Sevilla, ed. Miguel Ángel Castillo Oreja (Madrid, 2002), pp. 1-39.

Chao, David, Iconografía regia en la Castilla de los Trastámara (Universidad de Santiago de Compostela, 2005). 
Chapelot, Jean, "L'Hôtel du Roi á Vincennes: Charles V dans son logis," in La cour du prince. Cour de France, cours d'Europe, XII $-X V^{e}$ siècle, eds. Murielle Gaude-Ferragu, Bruno Laurioux, and Jacques Paviot (Paris, 2011), pp. 145-76.

Chilà, Rosa, "Castelnuovo, forteresse et résidence d'Alphonse le Magnanime a Naples" in Palacio y Génesis del Estado Moderno en los Reinos Hispanos. VI Jornadas Complutenses de Arte Medieval, eds. Pilar Martínez Taboada, Elena Paulino Montero, and Juan Carlos Ruiz Souza, Anales de Historia del Arte 23/2 (2013), pp. 431-44.

Cómez Ramos, Rafael, "Las casas del infante don Fadrique y el convento de Santa Clara de Sevilla," Historia, Instituciones, Documentos 34 (2007), 95-116.

Courting The Alhambra. Cross-disciplinary approaches to the Hall of Justice Ceiling, eds. Cynthia Robinson, and Simone Pinet (Special offprint of Medieval Encounters) 14/ 2-3 (Leiden, 2008).

Dessus Lamare, Alfred, “Étude sur le bahw, organe d'architecture musulmane," Journal Asiatique (1936), 529-47.

di Nicola, Enrico, "Arquitectura del siglo XV en Campania," in Una arquitectura gótica mediterránea 2, ed. Arturo Zaragozá Catalán (Valencia, 2003), pp. 99-114.

Domenge i Mesquida, Joan, "La gran sala de Castelnuovo. Memoria del Alphonsis regis triumphus," in Le usate leggiadrie. I cortei, le cerimonie, le feste e il costume nel Mediterraneo tra il XV e XVI secolo, Atti del convegno-Napoli, 14-16 dicembre 2006, ed. Gemma Teresa Colesanti (Montella 2010), pp. 290-338.

Ebersolt, Jean, Le Grand Palais de Constantinople et le Livre de Cérémonies (Paris, 1910). Featherstone, Jeffrey Michael, “The Great Palace as Reflected in the De Cerimoniis," in Visualisierungen von Herrschaft, ed. Franz Alto Bauer, Byzas 5 (Istanbul, 20o6), pp. 47-61.

Frommel, Christoph Luitpold, "Alberti e la porta trionfale de Castel Nuovo a Napoli," Annali di architecttura 20 (2008), 13-36.

Gámiz Gordo, Antonio, La Alhambra nazarí. Apuntes sobre su paisaje y arquitectura (Sevilla, 2001).

Gómez Redondo, Fernando, El desarrollo de los géneros. La ficción caballeresca y el orden religioso (Madrid, 1999).

Gómez Redondo, Fernando, Historia de la prosa medieval castellana. II El desarrollo de los géneros. La ficción caballeresca y el orden religioso (Madrid, 1999).

Grabar, Oleg, Ceremonial and Art at the Umayyad Court (Princeton University, 1955).

Hernández, Ignacio, "El Alcázar en tiempos de la dinastía trastámara," in El Alcázar de Segovia. Bicentenario 1808-2008, ed. Patronato de El Alcázar de Segovia (Segovia, 2010), pp. 95-112.

Howard, Deborah, "Venise et le Mamlûks," in Venise et l'Orient, ed. Stefano Carboni (Paris, 2006), pp. 72-89.

La Literatura en la época de Sancho IV, Actas del Congreso Internacional, Alcalá de Henares 21-24 de febrero de 1994, eds. Carlos Alvar, and José Manuel Lucía Megias (Alcalá de Henares, 1996). 
La planimetría del Alcázar de Sevilla, ed. Antonio Almagro Gorbea (Granada, 2000). Layna Serrano, Francisco, El Palacio del Infantado en Guadalajara (Guadalajara, 1997). Libro del Caballero Zifar, ed. Joaquín González Muela (Madrid, 199o).

Marquer, Julie, "El poder escrito: problemáticas y significación de las inscripciones árabes de los palacios de Pedro I de Castilla (1350-1369)," in Palacio y Génesis del Estado Moderno en los Reinos Hispanos. VI Jornadas Complutenses de Arte Medieval, eds. Pilar Martínez Taboada, Elena Paulino Montero, and Juan Carlos Ruiz Souza, Anales de Historia del Arte 23/2 (2013), pp. 499-508.

Martínez de Aguirre, Javier, Arte y monarquía en Navarra 1328-1425 (Pamplona, 1987).

Merino de Cáceres, José Miguel, "El Alcázar de los Austrias," in El Alcázar de Segovia. Bicentenario 1808-2008, ed. Patronato de El Alcázar de Segovia (Segovia, 2010), pp. $115^{-47}$.

Necipoglu, Gulru, "An outline of shifting paradigms in the palatial architecture of the pre-modern Islamic world," Ars Orientalis 23 (1993), 3-24.

Nogales Rincón, David, "Las series iconográficas de la realeza castellano-leonesa (siglos XII-XV)," En la España Medieval 1 (2006), 81-112.

Northedge, Alastair, "An interpretation of the Palace of the Caliph at Samarra (Dar alKhilafa or Jawsaq al-Khaqani)," Ars Orientalis 23 (1993), 143-70.

Oliva Muñoz, Pablo, Jiménez Sancho, Alfonso, and Tabales Rodríguez, Miguel Ángel, "Primera fase de estudios arqueológicos en el Real Monasterio de Santa Clara de Sevilla," Anuario Arqueológico de Andalucía 2003 1 (Sevilla, 2006), pp. 336-51.

Pérez Monzón, Olga, "Iconografía y poder real en Castilla. Las imágenes de Alfonso VIII," Anuario del Departamento de Historia y Teoría del Arte 16 (2002), 19-41.

Pérez Monzón, Olga, "La dimensión artística de las relaciones de conflicto," in La monarquía como conflicto en la Corona castellano-leonesa (c. 1230-1504), ed. José Manuel Nieto Soria (Madrid, 2006), pp. 547-62o.

Pérez Monzón, Olga, "Quando rey perdemos nunq[u] a bien nos fallamos. La muerte del rey en la Castilla del siglo XIII," Archivo Español de Arte, 8o/320 (2007), 379-94.

Pérez Monzón, Olga, "Ceremonias regias en la Castilla Medieval. A propósito del llamado 'Libro de la Coronación de los Reyes de Castilla y Aragón'," Archivo Español de Arte 83/332 (2010), 317-34.

Pérez Monzón, Olga, “'Ornado de tapicerías y aparadores de muchas vaxillas de oro e plata'. Magnificencia y poder en la arquitectura bajomedieval castellana," in Palacio y Génesis del Estado Moderno en los Reinos Hispanos. VIJornadas Complutenses de Arte Medieval, eds. Pilar Martínez Taboada, Elena Paulino Montero, and Juan Carlos Ruiz Souza, Anales de Historia del Arte 23/2 (2013), pp. 259-85.

Oliva Muñoz, Pablo, and Tabales Rodríguez, Miguel Ángel, "Los restos islámicos y el Palacio de don Fadrique," in Real Monasterio de Santa Clara. 2 Palacio y Cenobio, ed. José Solís Guzmán (Sevilla, 2007), pp. 13-21.

Puerta Vílchez José Miguel, Leer la Alhambra. Guía visual del monumento a través de sus inscripciones (Granada, 2010). 
Rabbat, Nasser, The Citadel of Cairo. A new interpretation of royal mamluk architecture (Leiden, 1995).

Rabbat, Nasser, Mamluk History through architecture. Monuments, Culture and Politics in Medieval Egypt and Syria (Cairo, 2010).

Rallo Gruss, Carmen, "El Castillo de Coca y su ornamentación," Anales de Historia del Arte 6 (1996), 13-34.

Poema de Alfonso Onceno, ed. Juan Victorio (Madrid, 1991).

Robinson, Cynthia, In praise of song. The Making of Courtly Culture in al-Andalus and Provence, 1005-1134 A.D. (Leiden, 2002).

Rodríguez Porto, Rosa María, "María de Molina y la Educación de Alfonso XI: la 'Semblanzas de Reyes' del Ms. 7415 de la Biblioteca Nacional," Quintana 5 (2006), 219-31.

Ruiz Hernando, Juan Antonio, "El Alcázar de Segovia, desde los orígenes al siglo XV," in El Alcázar de Segovia. Bicentenario 1808-2008, ed. Patronato de El Alcázar de Segovia (Segovia, 2010), pp. 45-91.

Ruiz Souza, Juan Carlos, "La Iglesia de Santa Clara de Tordesillas. Nuevas consideraciones para su estudio," Reales Sitios 36/140 (1999), 2-13.

Ruiz Souza, Juan Carlos, "La cúpula de mocárabes y el Palacio de los Leones de la Alhambra," Anuario del Departamento de Historia y Teoría del Arte 12 (2000), 9-24.

Ruiz Souza, Juan Carlos, "El palacio de los Leones de la Alhambra: ¿Madrasa, Zâwiya y Tumba de Muhammad V?," Al-Qantara 22/1 (2001), 77-120.

Ruiz Souza, Juan Carlos, "Santa Clara de Tordesillas. Restos de dos palacios contrapuestos (siglos XIII-XIV)," in Actas del V Congreso de Arqueología Medieval Española, Valladolid 1999 1 (Valladolid 2001), pp. 851-6o.

Ruiz Souza, Juan Carlos, "Castilla y Al-Andalus. Arquitecturas aljamiadas y otros grados de asimilación," Anuario del Departamento de Historia y Teoría del Arte (U.A.M.) 16 (2004), 17-43.

Ruiz Souza, Juan Carlos, “Tipología, uso y función del Palacio de Comares: nuevas lecturas y aportaciones sobre la arquitectura palatina," Cuadernos de la Alhambra 40 (2004), 77-102.

Ruiz Souza, Juan Carlos, “Toledo entre Europa y Al-Andalus en el siglo XIII: Revolución, tradición y asimilación de las formas artísticas en la Corona de Castilla," Journal of Medieval Iberian Studies 1/2 (2009), 256-65.

Ruiz Souza, Juan Carlos, "El Palacio Especializado y la Génesis del Estado Moderno. Castilla y Al-Andalus en la Baja Edad Media", in La Ciudad Medieval: de la casa principal al palacio urbano, eds. Jean Passini, and Ramón Izquierdo Benito (Toledo, 2011), pp. 93-128.

Ruiz Souza, Juan Carlos, “Rodrigo Jiménez de Rada, Alfonso X y Pedro I ante las 'reliquias arquitectónicas' del pasado en la construcción de la identidad de España. Historicismos antiguos," in Reyes y prelados: la creación artística en los reinos de León 
y Castilla (1050-150o), eds. María Dolores Teijeira Pablos, María Victoria Herráez Ortega, and María Concepción Cosmen Alonso (Madrid, 2014), pp. 219-3o.

Ruiz Souza, Juan Carlos, "El Palacio de la Montería del Alcázar de Sevilla. Contrapunto y futuro en el tardogótico," in 1514. Arquitectos tardogóticos en la encrucijada, eds. Begoña Alonso Ruiz, and Juan Clemente Rodríguez Estévez (Sevilla, 2016), pp. 319-37.

Ruiz Souza, Juan Carlos, "El Palacio de los Leones. Al-riyāḍ al-sa'īd, el Jardín Feliz del Conocimiento," in Domus Hispanica: el Real Colegio de España en la historia del arte (1364-2014), ed. Manuel Parada López de Corselas (Bolonia, 2017), pp. 195-210.

Ruiz Souza, Juan Carlos, "El Palacio de los Leones de la Alhambra: Espacio de Virtud del Príncipe," in The Power of Symbols: The Alhambra in a Global Context, eds. Francine Giese, and Ariane Varela (Berlin, 2018), pp. 79-92.

Ruiz Souza, Juan Carlos, "Fachadas parlantes. Escritura en la escenografía del poder," in Écritures du pouvoir - Les cultures politiques dans la péninsule Ibérique et au Maghreb, VIIIe - XVe siècles 2, ed. Véronique Lamazou-Duplan, Scripta Medieaevalia 38 (Bordeaux, 2019), pp. 181-94.

Salas Parrilla, Miguel, El Castillo de Belmonte (Madrid, 2010).

Sendebar, ed. María Jesús Lacarra (Madrid, 2007).

Serra Desfilis, Amadeo, "Promotores, tradiciones e innovación en la arquitectura valenciana del siglo XV," Goya 334 (2011), 58-73.

Tabales Rodríguez, Miguel Ángel, "Investigaciones arqueológicas en la Portada de la Montería del Alcázar de Sevilla," Apuntes del Alcázar de Sevilla 7 (2006), 6-39.

Tabales Rodríguez, Miguel Ángel, "Novedades arqueológicas relativas a los palacios medievales de Don Fadrique y Alcázar Real," in La herencia de Al-Andalus, ed. Fátima Roldán (Sevilla, 2007), pp. 123-32.

Tabbaa, Yasser, "Circles of power: palace, citadel and city in ayyubid sAleppo," Ars Orientalis 23 (1993), 143-70.

Vingtain, Dominique, Avignon. Le Palais des Papes (Auxerre, 1998). 


\section{Illustrations}

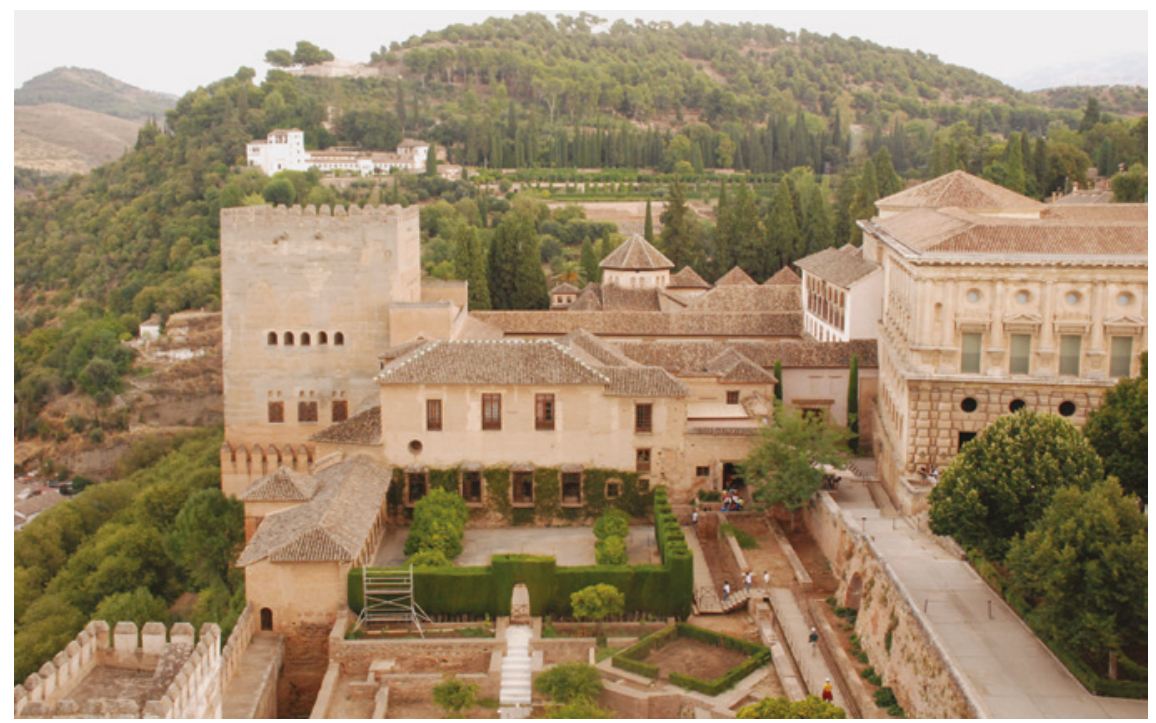

FIGURE 14.1 Alhambra of Granada, 14th century Pното: AUTHOR

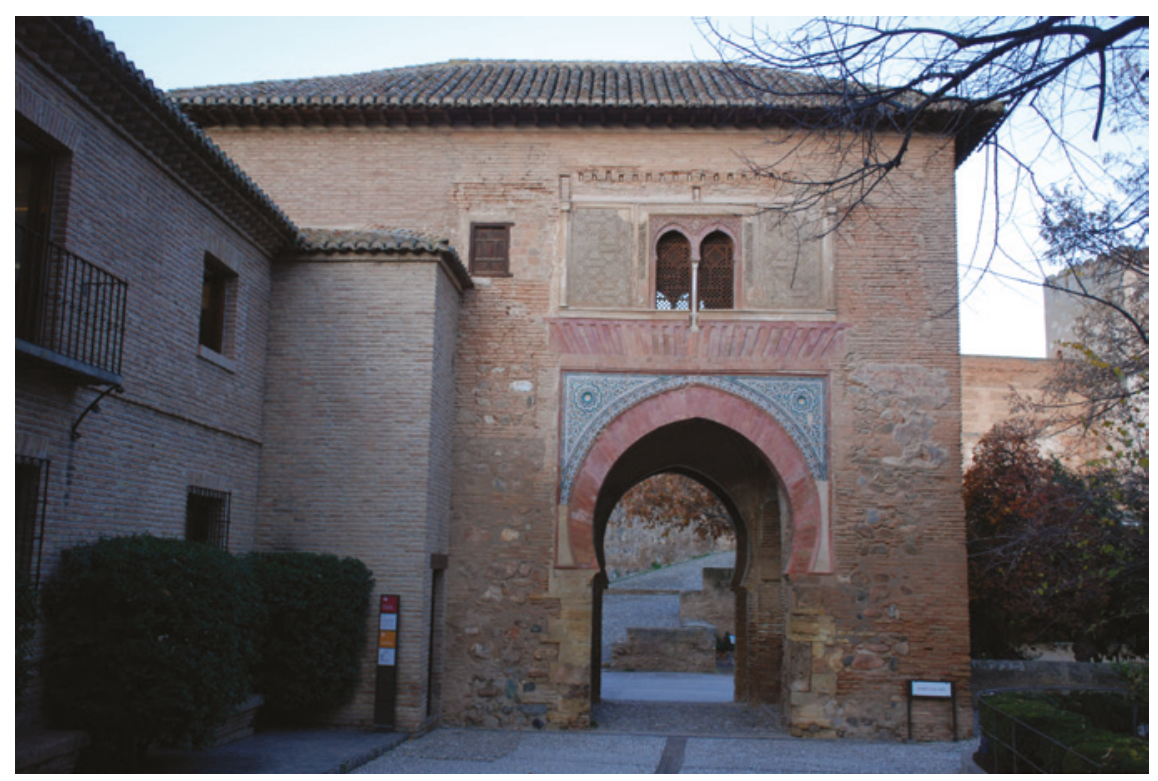

FIGURE 14.2 Wine Gate. Alhambra, 14th century PHOTO: AUTHOR 


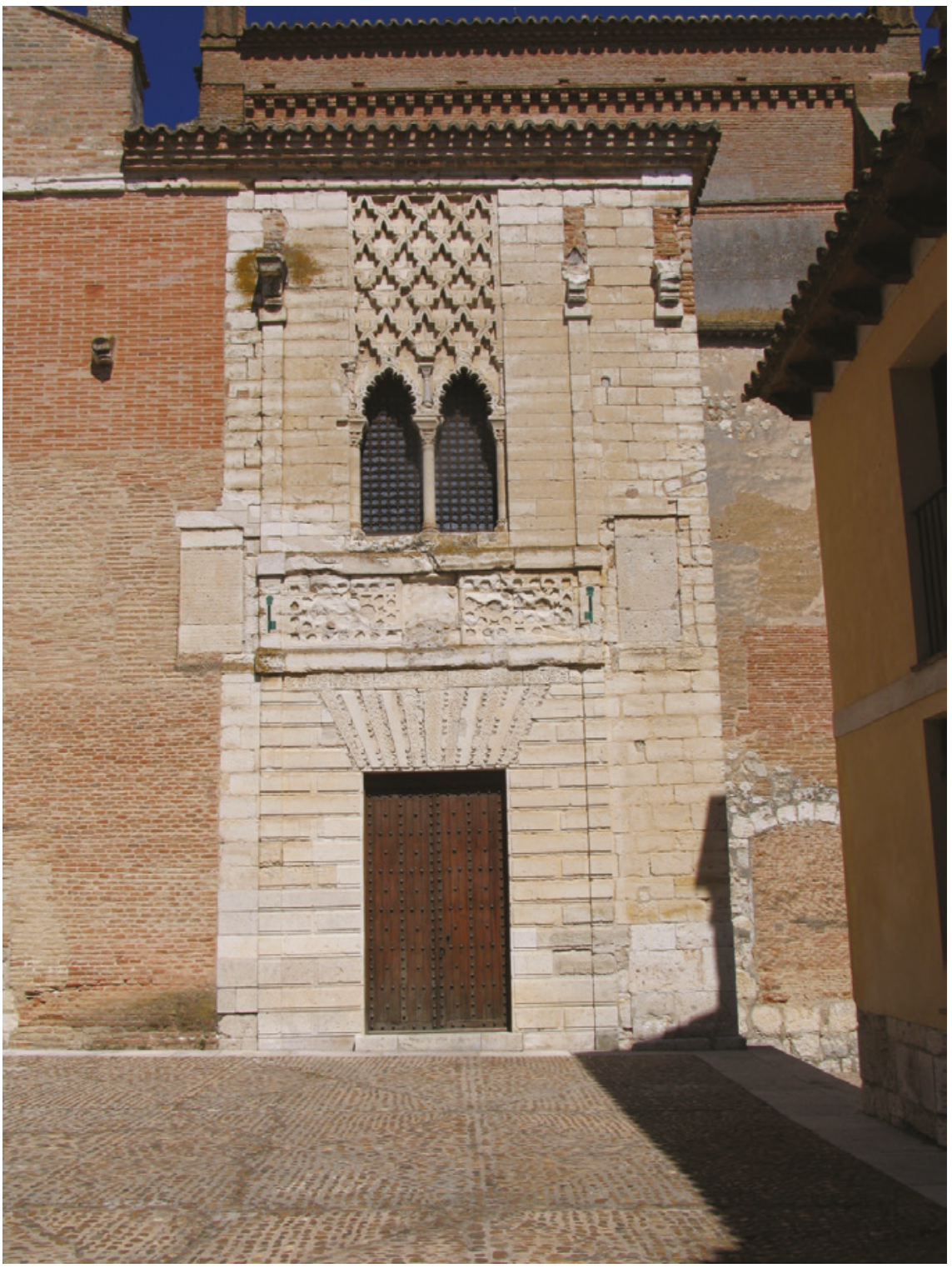

FIGURE 14.3 Façade of the palace of Santa Clara de Tordesillas (Valladolid), c. 136o PHOTO: AUTHOR 


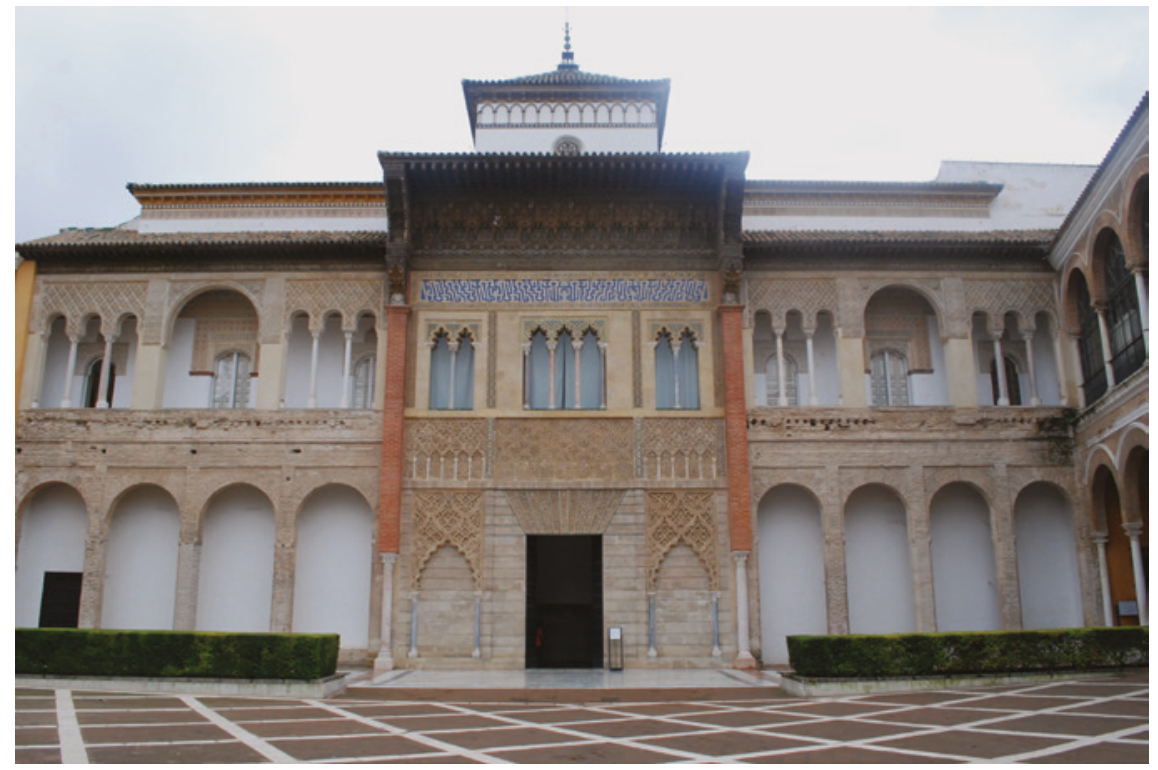

FIGURE 14.4 Façade of Montería. Alcázar of Seville, c. 1364 Pното: AUTHOR

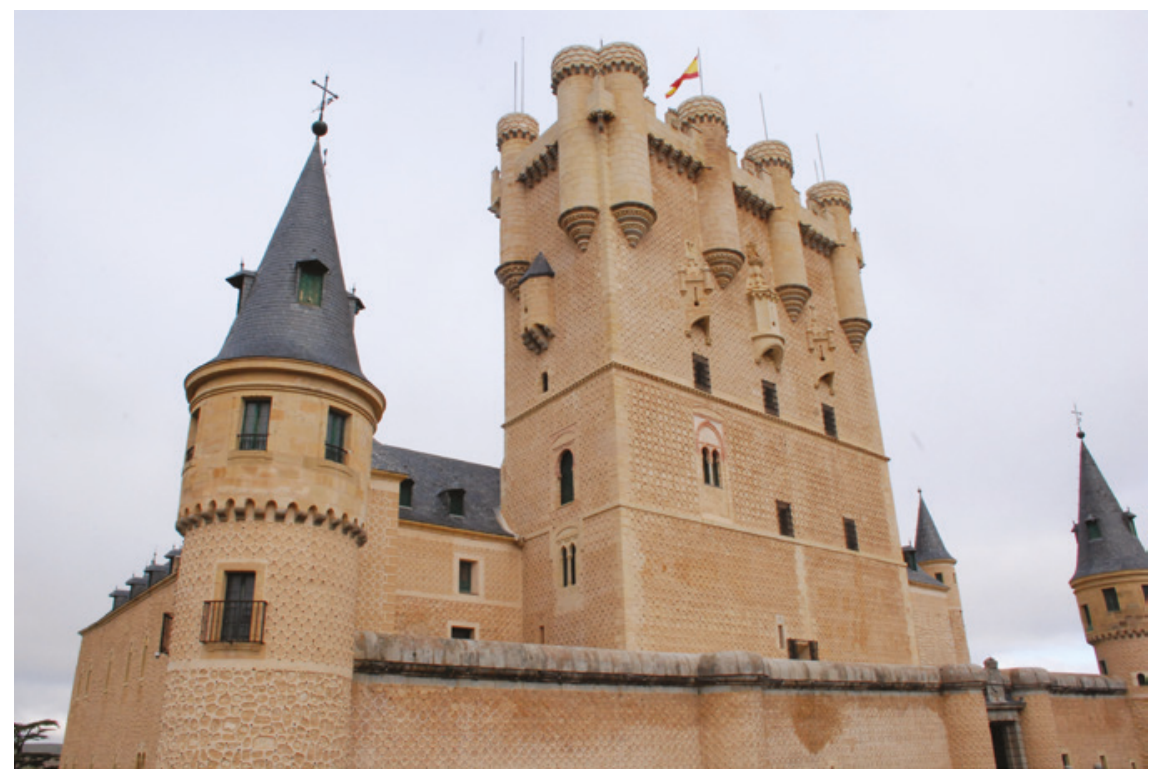

FIGURE 14.5 Tower of Juan II, first half of the $15^{\text {th }}$ century Segovia Pното: AUTHOR 


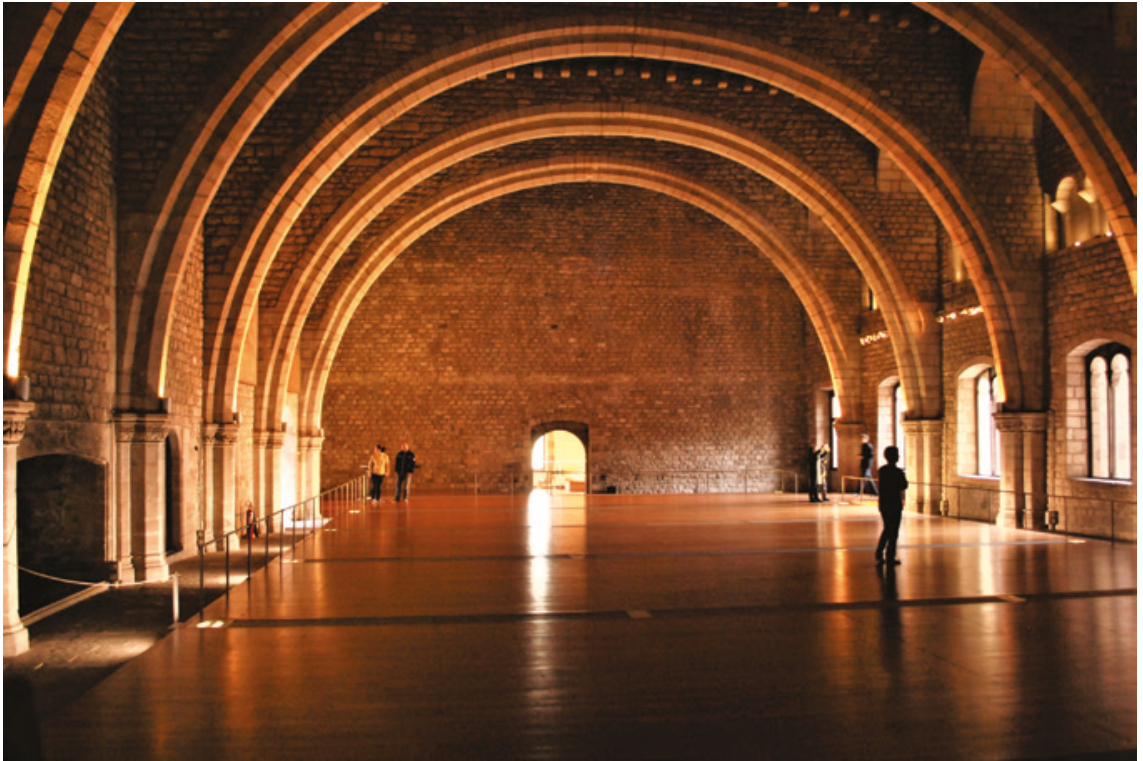

FIGURE 14.6 Saló del Tinell of the Royal Palace of Barcelona, 14th century рното: AUTHOR

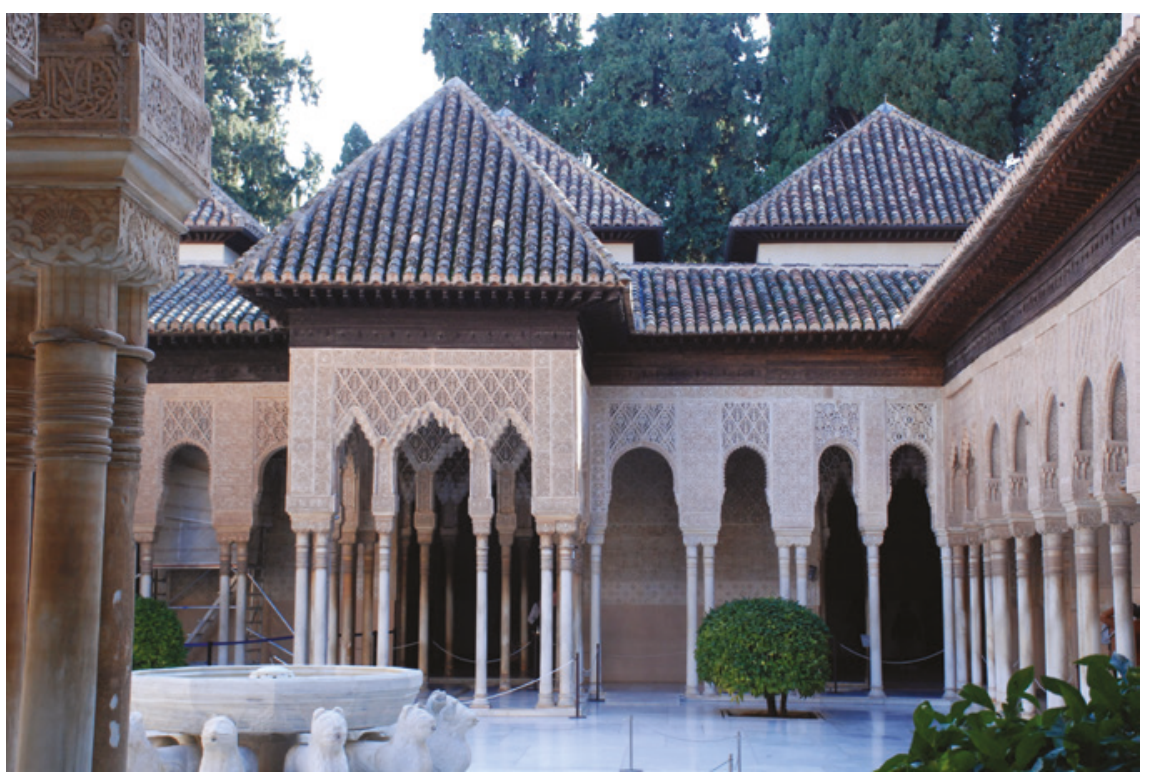

FIGURE 14.7 Court of Lions, Virtue Palace of Muhammad v. Alhambra, 14th Century PHOTO: AUTHOR 


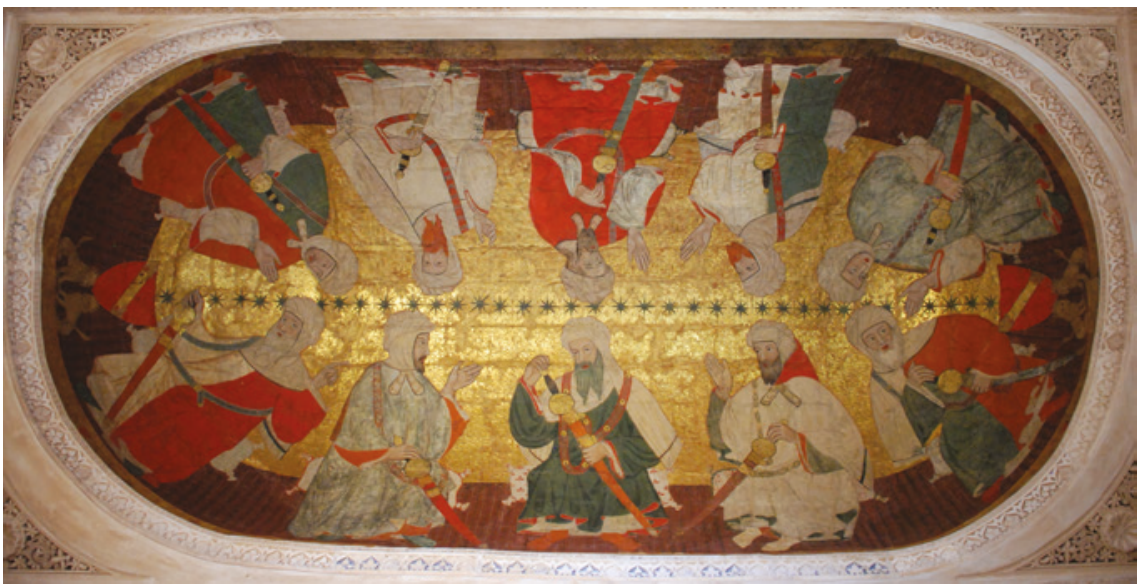

FIGURE 14.8 Maylis of Muhammad v with his wise men. King's hall, Court of Lions. Alhambra, 14th century Pното: AUTHOR

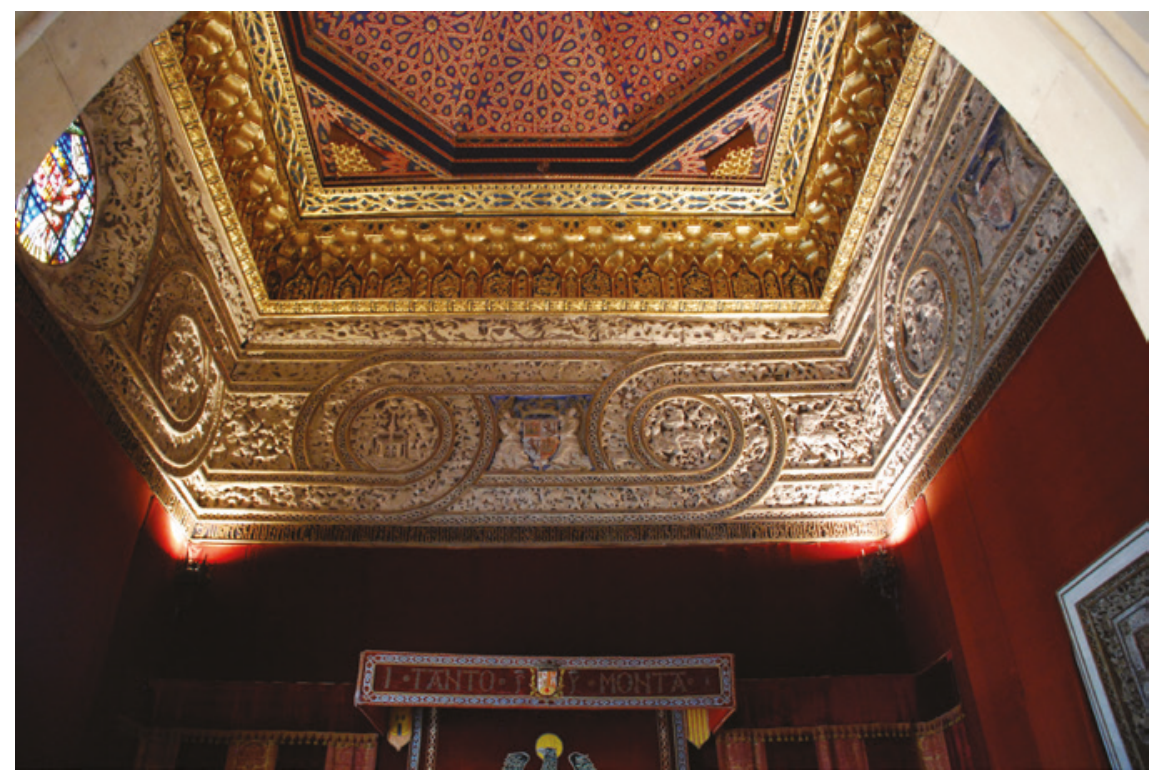

FIGURE 14.9 Salón del Solio. Alcázar of Segovie, 15th century Рното: AUTHOR 


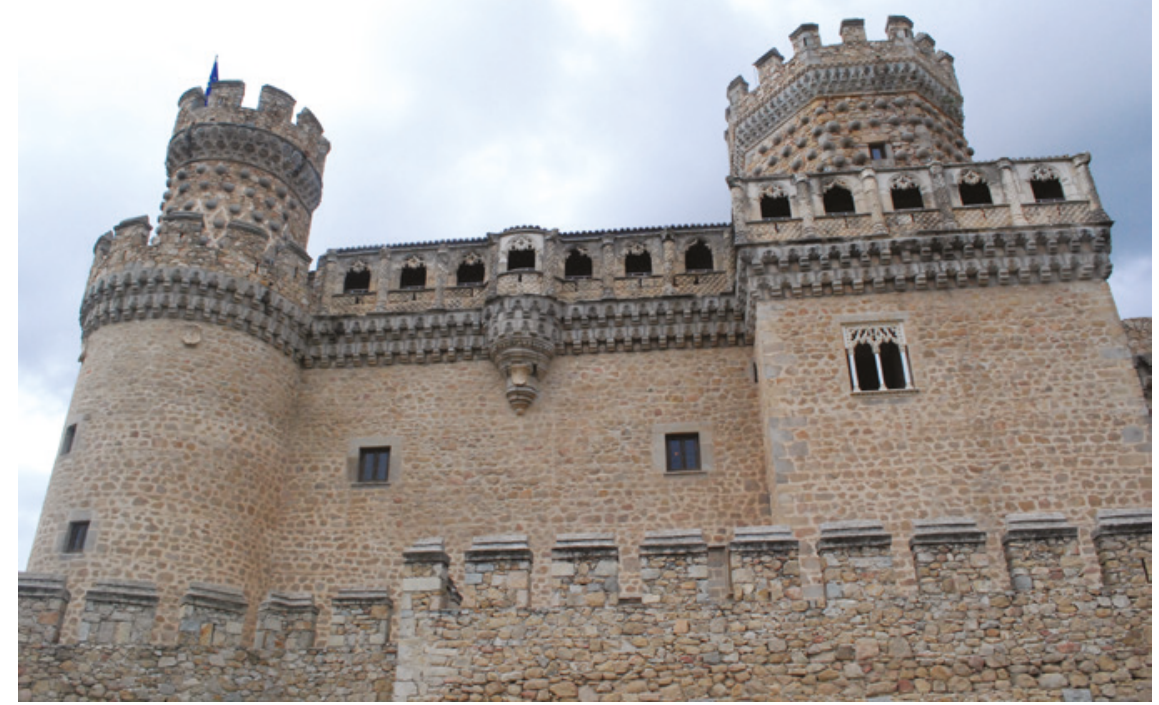

FIGURE 14.10 Castle Palace of Manzanares el Real. Andamios at the top of the wall, last quarter of the 15th century

PHOTO: AUTHOR

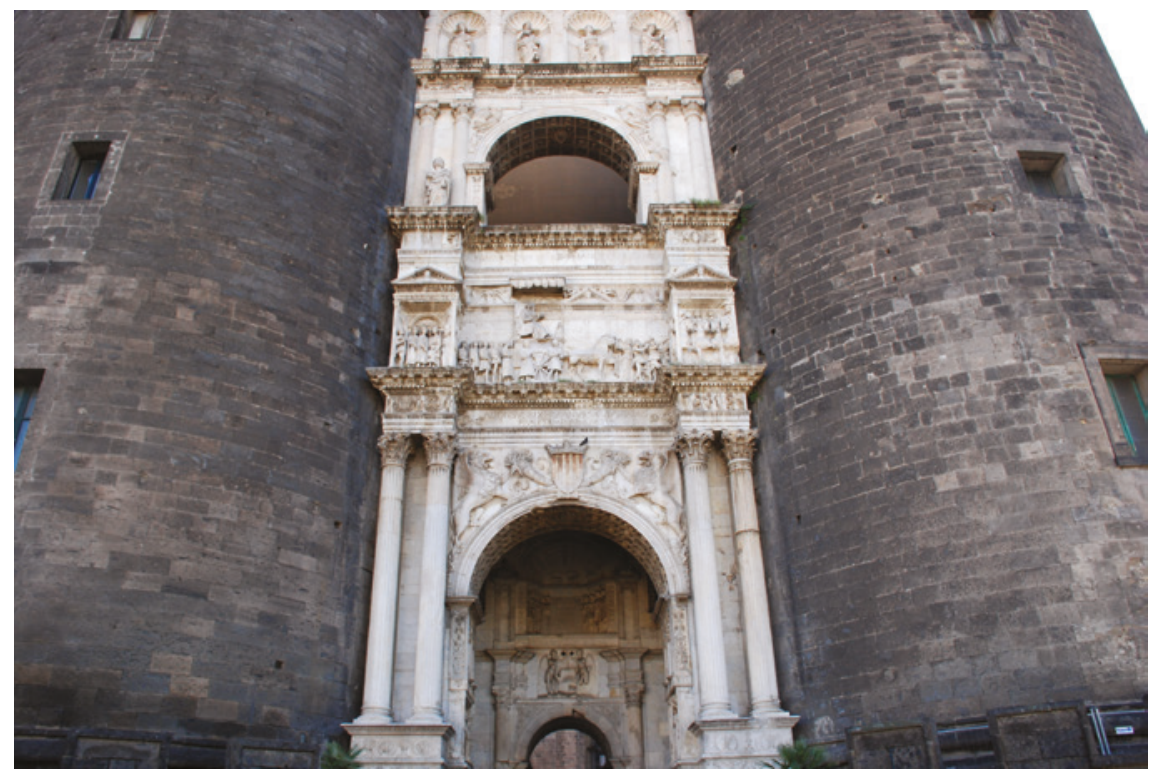

FIGURE 14.11 Main gate of Castelnuovo, Naples, 15th century PHоTO: AUTHOR 


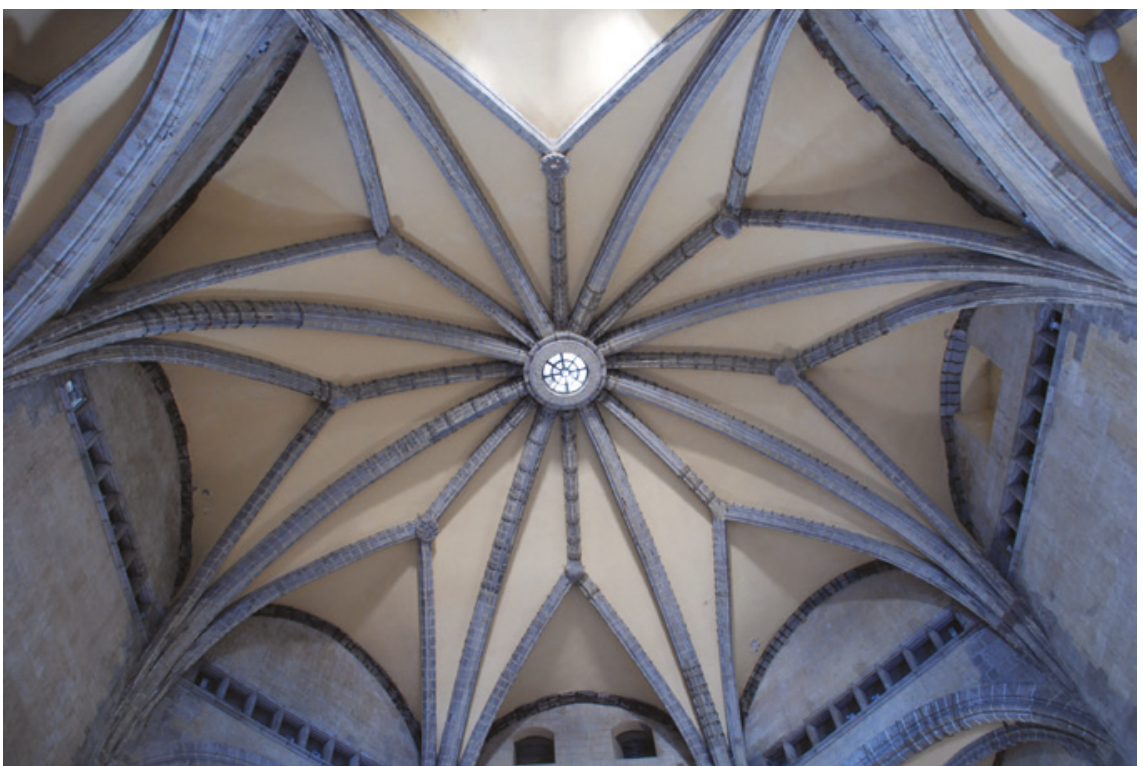

FIGURE 14.12 Sala dei Baroni, Naples, 15th century PHOTO: AUTHOR 
Juan Carlos Ruiz Souza - 9789004511583

Downloaded from Brill.com04/26/2023 03:47:21AM via free access 